\title{
Recent Operation and Life of Blast Furnace in Japan*
}

\author{
By Tetsuo IZAWA**
}

\section{Synopsis}

In this report, a few recent topics relating to blast furnaces in Japanlow productivity operation-high fuel ratio operation of large blast furnaces $\left(1.0 \sim 1.5 \mathrm{t} / \mathrm{day} \cdot \mathrm{m}^{3}\right.$ inner volume $)$, the life of blast furnaces and recent new technology-the injection of pulverized coal and low silicon operation, are mentioned.

\section{Introduction}

The progress of blast furnace operations in Japan has been remarkable. However, after registering a record hot metal production of 90.12 million $t$ in 1974, there has been a drastic reduction in production due to radical changes in the world economic climate. The steel industry is entering an era which is entirely different from anything experienced before.

Since the mid-nineteen fifties, blast furnaces have become increasingly larger and aggressive efforts have been made to operate at high production levels and to achieve a low fuel ratio by introducing self-fluxing sinter, more thorough screening of burden, high top pressure operation, and by advances made in composite blast technology. Through these efforts, productivity above $2.4 \mathrm{t} / \mathrm{day} / \mathrm{m}^{3}$ and daily hot metal production of $10000 \mathrm{t}$ have become routine. However, the two oil crises occurring in 1974 and 1978 completely forced the industry to deviate from its long standing course, where super large blast furnace and high productivity are most predominant.

Blast furnace has to be plummeted into the operation putting more emphasis on low productivity, energy saving and oil conservation. Among the advances in blast furnace technology made after the oil crises, are surely noteworthy the employment of higher percentage of processed ore in burden, probe and measuring techniques and computer control system.

But this report concentrates on the following.

1) End of the trend toward larger blast furnaces. Low productivity operation

2) Blast furnace operating methods with particular emphasis on the total energy balances of steel mills, and oil-free operation

3) Established burden distribution techniques

4) Control of hot metal chemistry

5) Analysis of blast furnace inside conditions

6) Life of blast furnaces

\section{End of the Trend toward Larger Blast Furnaces. Low Productivity Operation}

Crude steel production in Japan grew steadily until
1973 when production reached 119 million $t$, representing $17 \%$ of world production. Since then, production in Japan has fallen to the neighborhood of 100 million $t$, and in 1983 production is estimated to total 90 to 94 million $\mathrm{t}$.

The hot metal production of blast furnaces increased in parallel with increases in crude steel production, peaking at 90.12 million $t$ in 1974. The current production level is approximately 80 million $t$. (See Fig. 1.)

Of the 66 blast furnaces in Japan with a total capacity of $168800 \mathrm{~m}^{3}$ in inner volume at the end of 1982 , only 40 blast furnaces totaling $117100 \mathrm{~m}^{3}$ in inner volume were in operation. The hot metal production totaled only 80.6 million t. (See Fig. 2.) After Sumitomo Metals built its Kashima No. 3 BF with a capacity for $5050 \mathrm{~m}^{3}$ in 1976 , the trend toward constructing large blast furnaces has stopped. While the steel companies are reducing output, small blast furnaces have been lying idle. There are now only a few blast furnaces with capacities of less than 2000 $\mathrm{m}^{3}$. The average productivity of those blast furnaces in operation has been gradually falling. (See Fig. 3.)

Figure 4 presents the relationship between blast furnace productivity and inner volume for five major

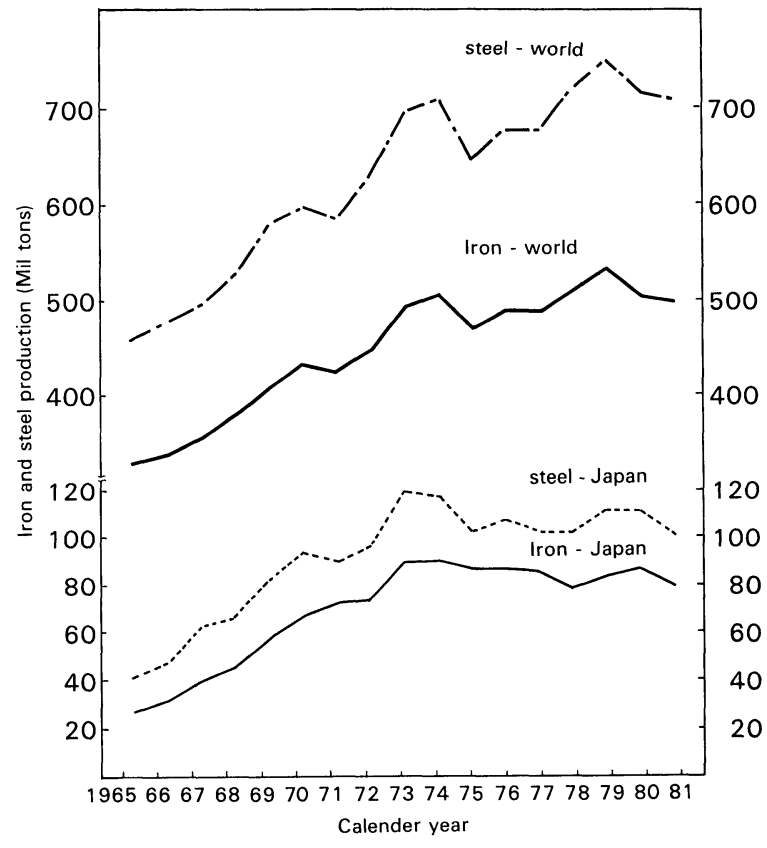

Fig. 1. Iron and Steel production-World and Japan.

* Keynote Address held at the Joint Symposium of The Iron and Steel Institute of Japan and The Australasian Institute of Mining and Metallurgy, October, 1983, in Tokyo. Manuscript received February 3, 1984. (C) 1984 ISIJ

** Chairman of Ironmaking Committee, The Joint Research Society, The Iron and Steel Institute of Japan; General Manager, Engineering, Research \& Development Div., Planning and Coordination Dept., Nippon Kokan K.K., Marunouchi, Chiyoda-ku, Tokyo 100. 
steel companies in Japan. As a general trend, productivity of large blast furnaces are being maintained at high levels, while those of small furnaces at low levels. The reasons for this are that the large blast furnaces are new and ultramodern and the desire of the steel companies is to preserve them because of the large investments they represent. Technically, operating super large blast furnaces at low productivity presents difficulties in terms of gas distribution and

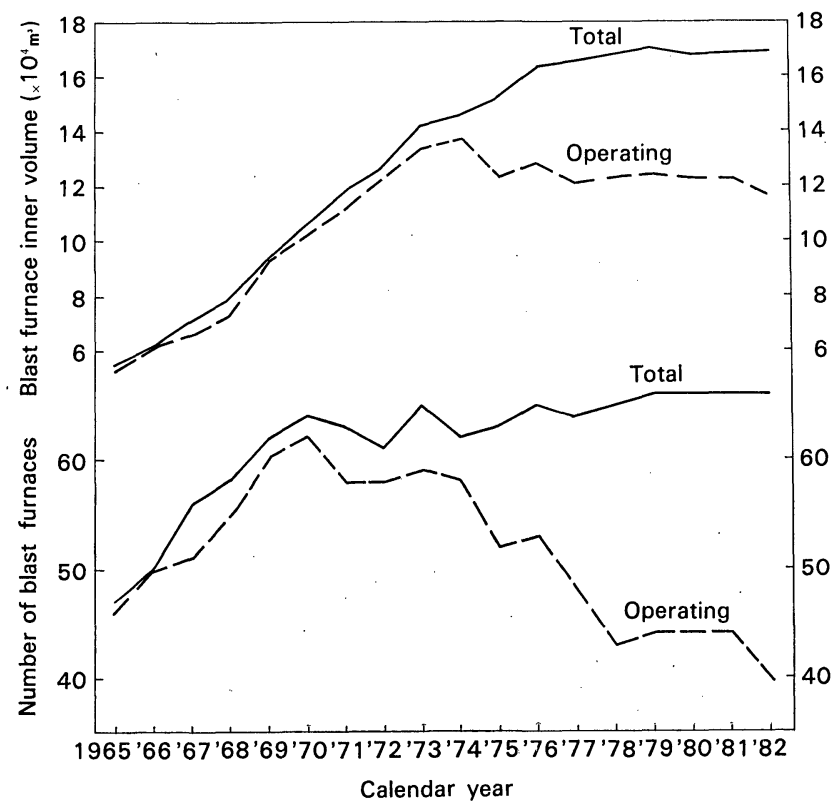

Fig. 2. Progress of number of blast furnaces and blast furnace inner volume in Japan. heat control. In some instances these include problems such as scabs produced inside furnaces, and the difficulty of discharging slag, although the situation has been greatly improved recently through the rapid progress made in operating technology. Nevertheless, the technology to provide for flexible production depending on economic fluctuations is difficult to realize in practice regardless of the capacities of blast furnaces, and efforts should be made to improve the technology in that direction.

\section{Blast Furnace Operating Methods with Par- ticular Emphasis on the Total Energy Balances of Steel Mills and Oil-free Oper- ation}

The use ratio of coal in the energy consumption breakdown of integrated steel mills has been high from the beginning. This trend has been accelerated by the two oil crises. Figure 5 shows an example from Kashima Steel Works of Sumitomo Metal Industries, Ltd. Prior to the second oil crisis, in 1979, the breakdown was $88.1 \%$ for coal, $4.6 \%$ for fuel oil, and $7.3 \%$ for purchased electricity. In 1981, the energy consumption breakdown had become $95.5 \%$ for coal, $4.5 \%$ for purchased electricity and $0 \%$ for fuel oil, through efforts made in reducing fuel oil consumption such as stopping the practice of injecting fuel oil into blast furnaces. A similar situation exists with respect to other steel mills in Japan. In the past, $50 \%$ of the fuel oil burned in a steel mill was consumed by blast furnaces. The so-called all-coke operations have been realized in the steel mills to substitute this fuel

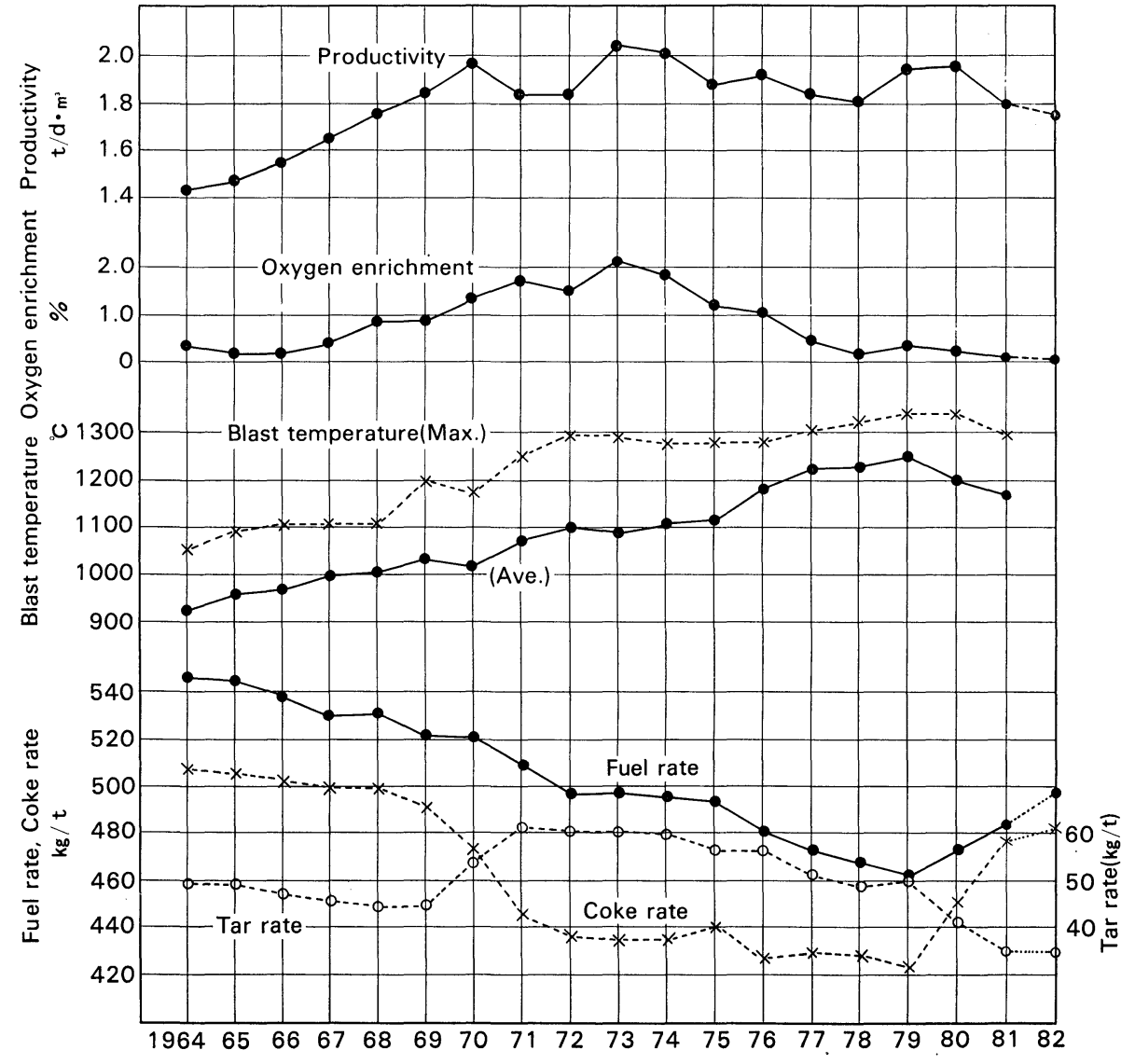

Fig. 3.

Progress of major operating indices for Japanese blast furnaces. 
Fig. 4.

Relation between blast furnace productivity and inner volume of five major steel companies in Japan for 1982.
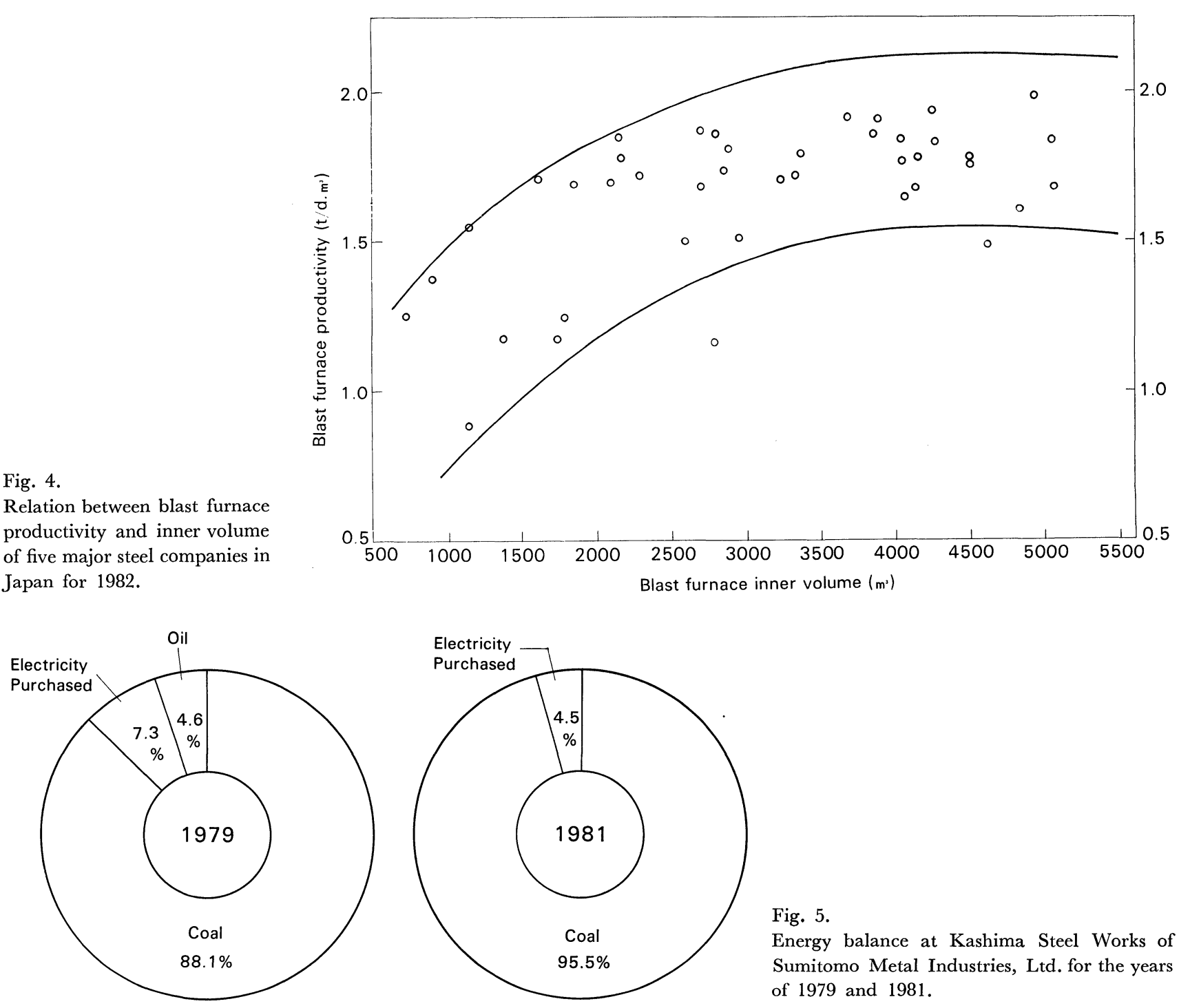

Fig. 5.

Energy balance at Kashima Steel Works of Sumitomo Metal Industries, Ltd. for the years of 1979 and 1981.

oil for coke. Blast furnace and coke oven gases produced are fed to power plants, heating furnaces, and boilers to save petroleum fuels.

Of the 53 blast furnaces operating in Japan in January, 1977, 40 were using fuel oil, 12 were also using tar, and one was consuming only coke. In December, 1982, however, of 40 blast furnaces, 26 were consuming only coke, 12 were consuming tar, 1 heavy oil, and another pulverized coal. These figures indicate the rapid changes made in the operating mode of the blast furnaces. Table 1 shows data for the all-coke operations at Nippon Kokan.

In all-coke operations, a large number of blast furnaces are operating on the basis of low blast temperature and a high coke ratio to pursue economic advantages. When fuel oil injection is cut, the flame temperature at the tuyere cannot be maintained at the same level when the blast furnace operating conditions are to be maintained. The blast furnaces must then be operated by slightly lowering the blast temperature, or increasing the blast humidity. Through this operation, gases can be used more effectively in the rolling mill area and power plant. At present, attempts are being made to maintain the blast temperature as low as possible, and some blast furnaces
Table 1. All coke operation at Nippon Kokan K. K.

\begin{tabular}{|c|c|c|c|}
\hline & $\begin{array}{c}\text { Fukuyama } \\
\text { 3BF }\end{array}$ & $\begin{array}{c}\text { Fukuyama } \\
3 \mathrm{BF}\end{array}$ & $\underset{1 \mathrm{BF}}{\text { Ohgishima }}$ \\
\hline Period & $\begin{array}{c}\text { 3rd quater } \\
1979\end{array}$ & $\begin{array}{l}\text { June } \\
1980\end{array}$ & $\begin{array}{c}\text { March } \\
1983\end{array}$ \\
\hline Production $(t / d)$ & 6411 & 6950 & 6778 \\
\hline Productivity $\left(\mathrm{t} / \mathrm{d} \cdot \mathrm{m}^{3}\right)$ & 2.00 & 2.16 & 1.67 \\
\hline Coke rate $(\mathrm{kg} / \mathrm{t})$ & 412 & 459 & 503 \\
\hline $\begin{array}{l}\text { Heavy oil (Tar) rate } \\
(\mathrm{kg} / \mathrm{t})\end{array}$ & 30 & - & - \\
\hline Fuel rate $(\mathrm{kg} / \mathrm{t})$ & 442 & 459 & 503 \\
\hline Blast volume $\left(\mathrm{Nm}^{3} / \mathrm{min}\right)$ & 4743 & 5222 & 5993 \\
\hline Blast pressure $\left(\mathrm{kg} / \mathrm{cm}^{2}\right)$ & 2.90 & 3.44 & 3.54 \\
\hline Blast temperature $\left({ }^{\circ} \mathrm{C}\right)$ & 1319 & 1269 & 948 \\
\hline Blast moisture $\left(\mathrm{g} / \mathrm{Nm}^{3}\right)$ & 9 & 16 & 26 \\
\hline Top gas volume $\left(\mathrm{Nm}^{3} / \mathrm{t}\right)$ & 1256 & 1285 & 1482 \\
\hline $\begin{array}{l}\text { Hot stove heat con- } \\
\text { sumption }\left(10^{3} \mathrm{kcal} / \mathrm{t}\right)\end{array}$ & 526 & 512 & 380 \\
\hline Hot metal $(\% \mathrm{Si})$ & 0.34 & 0.38 & 0.40 \\
\hline$(\% \mathrm{~S})$ & 0.034 & 0.030 & 0.030 \\
\hline Remarks & $\begin{array}{l}\text { Heavy oil } \\
\text { injection }\end{array}$ & $\begin{array}{l}\text { All coke } \\
\text { operation } \\
\text { high pro- } \\
\text { ductivity }\end{array}$ & $\begin{array}{l}\text { All coke } \\
\text { operation } \\
\text { low pro- } \\
\text { ductivity }\end{array}$ \\
\hline
\end{tabular}



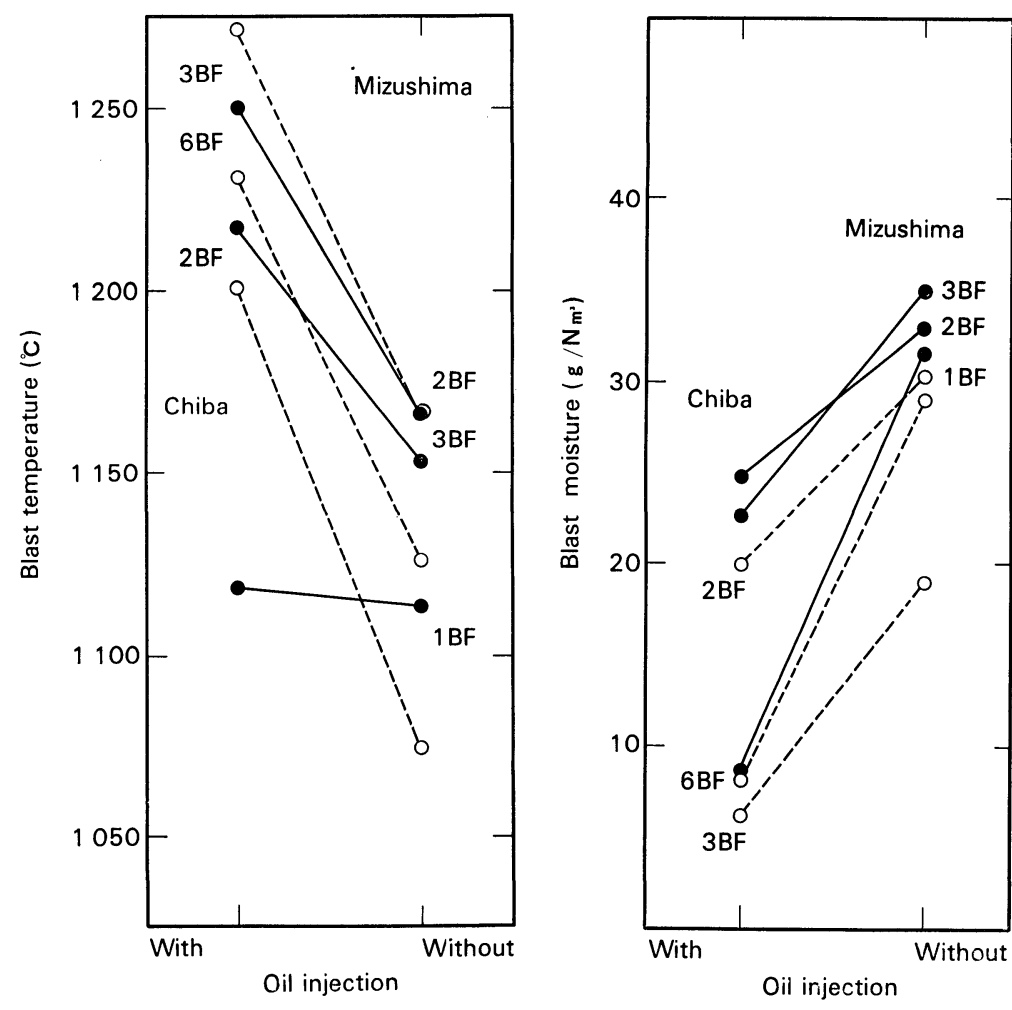

Fig. 6. Change of blast temperature and blast moisture by stop of oil injection.

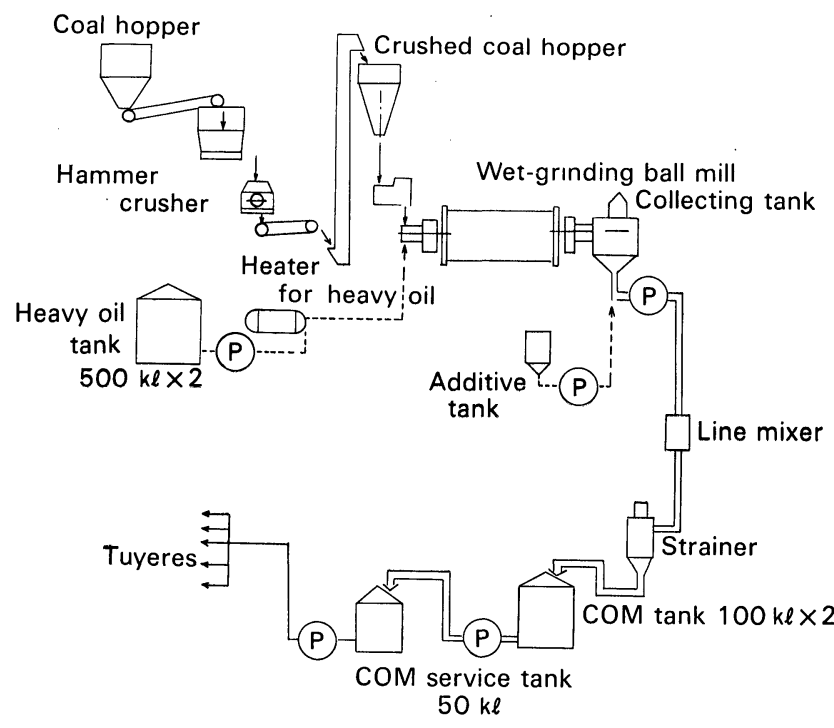

Fig. 7. Schematic flow of $20 \mathrm{t} / \mathrm{h}$ COM demo-plant at Kashima Steel Works of Sumitomo Metal Industries, Ltd.

are operated with blast temperature below $1000^{\circ} \mathrm{C}$ while blast temperature of $1300^{\circ} \mathrm{C}$ was attained during the 1970s. Figure 6 summarizes this situation.

As already stated, the bulk of the blast furnaces have adopted all-coke and tar injection operations. Depending on long-term stability of operations and the location of steel mills, approaches are being proposed to inject some auxiliary fuels to replace fuel oil. A fuel mixing fuel oil and pulverized coal (COMFig. 7, Sumitomo Metal, Kobe Steel, and others), a fuel mixing tar and pulverized coal (TCM-Nippon Kokan, Sumitomo Metal), pulverized coal, PGI (Fig. 8-Nippon Steel, Kobe Steel) and others have been studied. Some of these studies have found practical

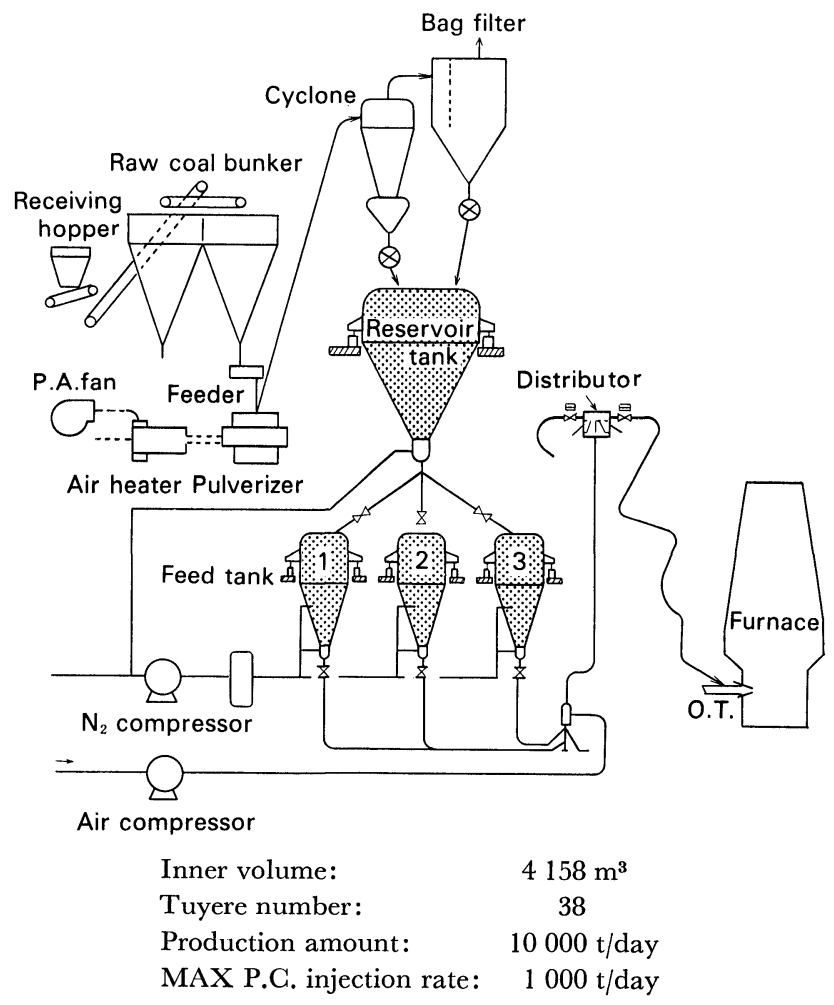

Fig. 8. Schematic flowsheet of PCI injection at Oita Works of Nippon Steel Corporation.

applications. Because of its payability compared with fuel oil and the problems in transporting and storing coal to prevent explosions, PGI has not been used in Japan. However, since 1977, PGI has been receiving attention as the price difference between fuel oil and coal has widened.

In Japan in 1962, The University of Tokyo suc- 
ceeded in a test using an experimental blast furnace. Since then, however, Nippon Steel introduced the ARMCO process in May, 1981 and Kobe Steel the Petrocarb process, in March, 1983. Table 2 shows the operation of the No. $1 \mathrm{BF}$ at the Oita Works of Nippon Steel. The replacement ratio between oil and coal is 0.9 to 1.0 , and extremely good results have been obtained. Various types of injection are very important from the standpoint of the stability and high productivity of blast furnace operations regardless of whether or not fuel oil is used.

The only remaining problems are the payability and stability of blast furnace operations. The introduction of coal injection will be studied based on the price difference between oil and coal, the effective utilization of blast furnace and coke oven gases from the steel mills, and coke oven capacity. Coal injection is anticipated to be adopted in the future.

\section{Established Burden Distribution Techniques}

As a means to distribute burden charged into blast furnace at the furnace top, distribution control equipment such as the movable armour and bell-less type have been used since 1965. Their employment has precipitated prominent advances in parallel with the development of burden distribution measurement

Table 2. Operational result of PCI injection at NSC Oita Works.

\begin{tabular}{|c|c|c|c|}
\hline \multirow[b]{2}{*}{ Item } & \multicolumn{3}{|c|}{ Operation Period } \\
\hline & $\begin{array}{c}\text { Oil } \\
\text { injection } \\
\text { Nov. } 1979\end{array}$ & $\begin{array}{l}\text { All coke } \\
\text { Aug. } 1980\end{array}$ & $\begin{array}{c}\text { P.C.I. } \\
\text { Feb. } 1982\end{array}$ \\
\hline Production $(\mathrm{t} / \mathrm{d})$ & 7874 & 7626 & 7743 \\
\hline Productivity $\left(\mathrm{t} / \mathrm{d} / \mathrm{m}^{3}\right)$ & 1.89 & 1.83 & 1.86 \\
\hline Fuel rate $(\mathrm{kg} / \mathrm{t}-\mathrm{p})$ & 456.6 & 469.3 & 446.7 \\
\hline Injectant rate $(\mathrm{kg} / \mathrm{t}-\mathrm{p})$ & 34.6 & - & 52.3 \\
\hline Blast temperature $\left({ }^{\circ} \mathrm{C}\right)$ & 1281 & 1281 & 1293 \\
\hline Humidity $\left(\mathrm{g} / \mathrm{Nm}^{3}\right)$ & 2.2 & 23.2 & 12.6 \\
\hline Input $\mathrm{H}_{2}(\mathrm{~kg} / \mathrm{t}-\mathrm{p})$ & 6.75 & 5.29 & 6.29 \\
\hline Blast volume $\left(\mathrm{Nm}^{3} / \mathrm{t}-\mathrm{p}\right)$ & 1011 & 1094 & 972 \\
\hline $\mathrm{O} / \mathrm{G}(-)$ & 3.89 & 3.44 & 4.11 \\
\hline Slag rate $(\mathrm{kg} / \mathrm{t}-\mathrm{p})$ & 340 & 313 & 317 \\
\hline $\mathrm{FeO}$ in sinter $(\%)$ & 6.52 & 4.97 & 4.60 \\
\hline Solution loss $(\mathrm{kg} / \mathrm{t}-\mathrm{p})$ & 110.6 & 110.2 & 100.1 \\
\hline Top gas volume $\left(\mathrm{Nm}^{3} / \mathrm{t}-\mathrm{p}\right)$ & 1504 & 1561 & 1455 \\
\hline Temperature $\left({ }^{\circ} \mathrm{C}\right)$ & 118 & 133 & 101 \\
\hline$\eta_{\mathrm{co}}\left(\mathrm{CO}_{2} / \mathrm{CO}+\mathrm{CO}_{2}\right)(\%)$ & 48.8 & 49.7 & 51.1 \\
\hline Si content $(\%)$ & 0.37 & 0.47 & 0.33 \\
\hline Pig iron temperature $\left({ }^{\circ} \mathrm{C}\right)$ & 1518 & 1528 & 1513 \\
\hline
\end{tabular}

methods such as mechanical sounding, laser, and microwave. It is no exaggeration to state that operations at a low productivity, low-Si operations, and low fuel ratio operations have been accomplished by the completion of this burden distribution technique. A detailed description of the distribution technique will not be given in this paper. Trends in the changes that have taken place in the charging equipment concerning movable armour and bell-less will be shown. (See Table 3.)

There seems to be almost no difference in operational performance so far between the bell-less and bell types. The former features ease of exchange during the campaign and lightweight design. The latter features no necessity for repairs for one campaign and fewer failures, even though its bell is large.

\section{Control of Hot Metal Chemistry}

One characteristic of the integrated steel mills in Japan is that the hot metal ratio of converters is extremely high, 90 to $98 \%$. For this reason, the silicon content in pig iron is required to be below $0.30 \%$ and in converters, the so-called slag minimum operation is pursued.

Recently, so called slagless operation has been introduced in converters, where primarily decarburization occurs in converter, while dephosphorization and desulphurization take place outside. As a prerequisite for this process, the silicon content in pig iron is required to be 0.15 to $0.10 \%$. For this reason, the so-called low silicon operations to lower the silicon content as much as possible, which has been an index for furnace heat in the past, has been employed.

Several theories have been introduced on the transfer of silicon to pig iron in blast furnaces. Generally, $\mathrm{SiO}$ gases produced from ash in coke at tuyere are considered to transfer to pig iron. Therefore, to suppress the transfer of $\mathrm{SiO}(\mathrm{G})$ - $\mathrm{Si}(\mathrm{M}),(1)$ lowering of the level of melting zone, (2) suppression of PSiO at tuyere by lowering the tuyere temperature, (3) not increasing the heat flow ratio, (4) lowering the hot metal temperature, and other steps are taken.

Figure 9 shows the relationship between the fractional volume of the dropping zone and silicon content in pig iron estimated for the No. $3 \mathrm{BF}$ in Chiba Works of Kawasaki Steel. The figure shows that the silicon content is reduced as the cross sectional area of the melting zone decreases. Blast furnaces featuring advanced operations with the lowest silicon content using the foregoing techniques have attained $0.20 \%$ per month on average. As shown in Fig. 10, the average for all the blast furnaces is also gradually falling.

Table 3. Progress of number of bell-less and bell+movable armour charging equipments in Japan.

\begin{tabular}{l|rrrrrrrrrr}
\multicolumn{1}{c}{ Type } & \multicolumn{10}{c}{ Year } \\
\cline { 2 - 10 } & 1973 & 1974 & 1975 & 1976 & 1977 & 1978 & 1979 & 1980 & 1981 & 1982 \\
\hline Number of blast furnaces installed & 71 & 71 & 72 & 72 & 68 & 69 & 66 & 66 & 66 & 66 \\
Bell-less type & 1 & 2 & 2 & 4 & 5 & 5 & 6 & 6 & 7 & 7 \\
Bell+movable armour type & 21 & 25 & 31 & 37 & 38 & 39 & 37 & 39 & 40 & 40 \\
Bell type & 49 & 44 & 39 & 31 & 25 & 25 & 23 & 21 & 19 & 19 \\
\hline
\end{tabular}




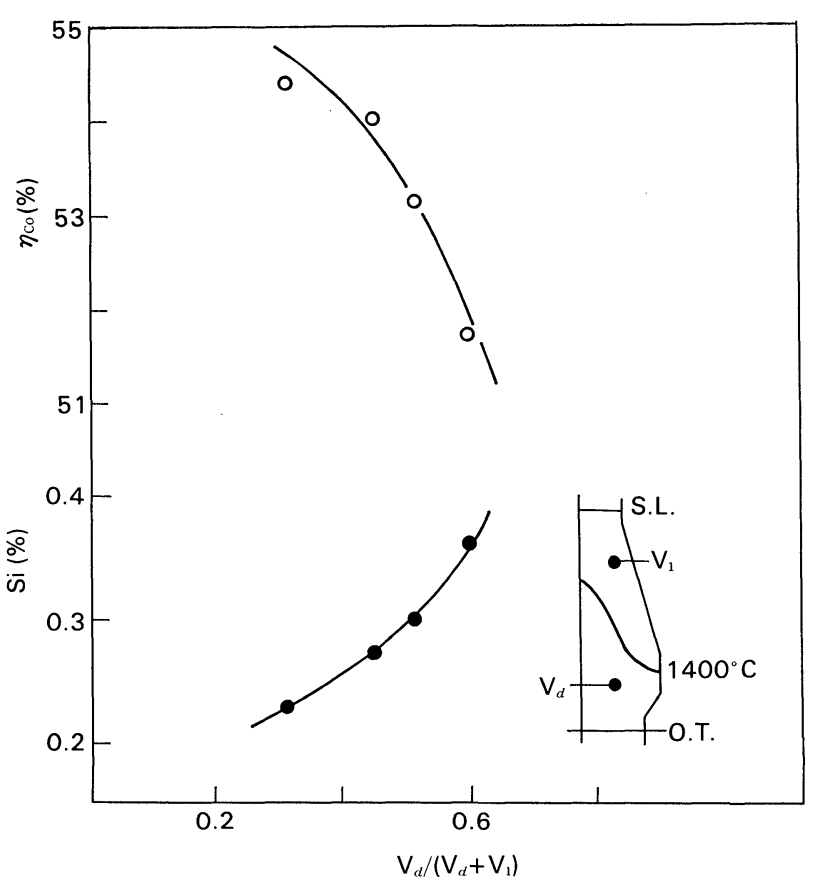

As shown in Fig. 11, a continuous hot metal desiliconization technique has recently been developed, to desiliconize by charging iron oxide such as mill scale directly into a runner in the casthouse. The technology has been used in some steel mills. Recently, the manganese content in pig iron has been reduced in some mills.

\section{Analysis of Blast Furnace Inside Conditions}

In the 5 to 6 years after 1971, several blown out blast furnaces were subject to disecting in Japan, providing extensive information and knowledge on many subjects including the existence of cohesive zone. The studies drastically enhanced the analysis of conditions inside blast furnaces which had been regarded as a black box. Thanks also to advances made in instrumentation sensor technology since then, as shown in Fig. 12, conditions inside blast furnaces can be displayed directly on a graphic panel to permit examination of furnace heat, gas distribution and other items including corrective measures.

Fig. 9. Changes of Si content in pig iron and of $\mathrm{CO}$ gas utilization with the fractional volume of dropping zone.

(Chiba No. 6 BF, Kawasaki Steel Corporation)

Fig. 10.

Progress of hot metal chemistry of Japanese blast furnaces.

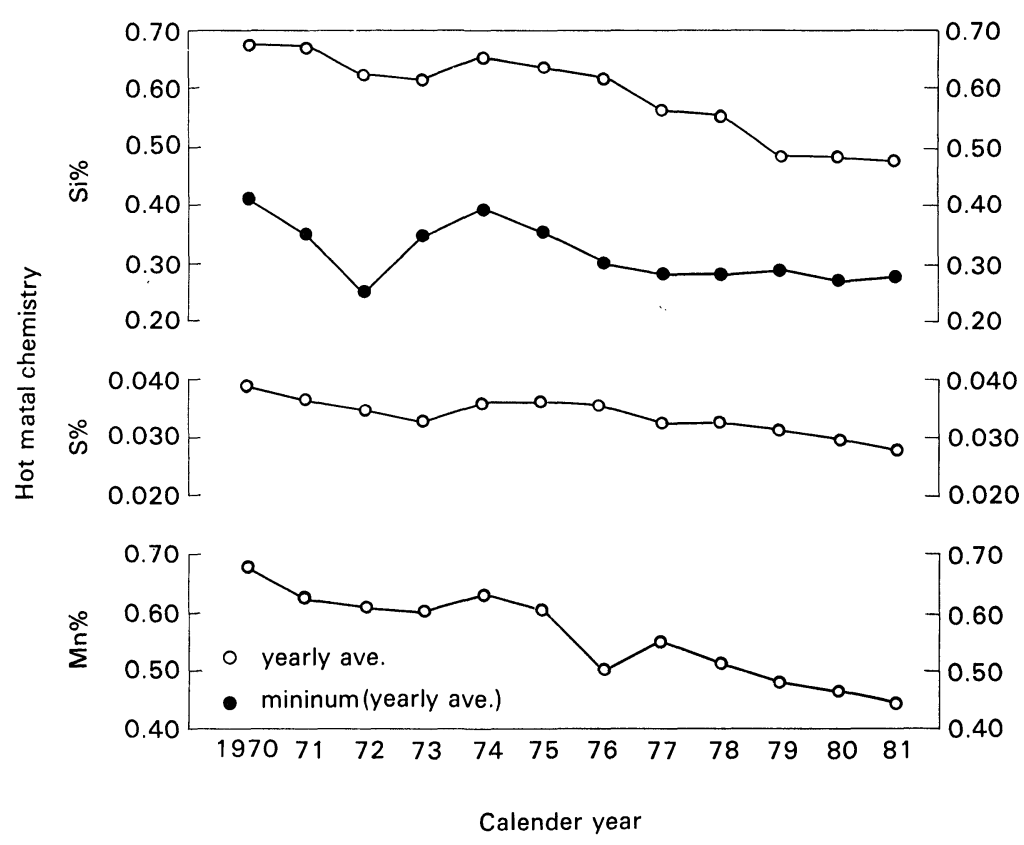

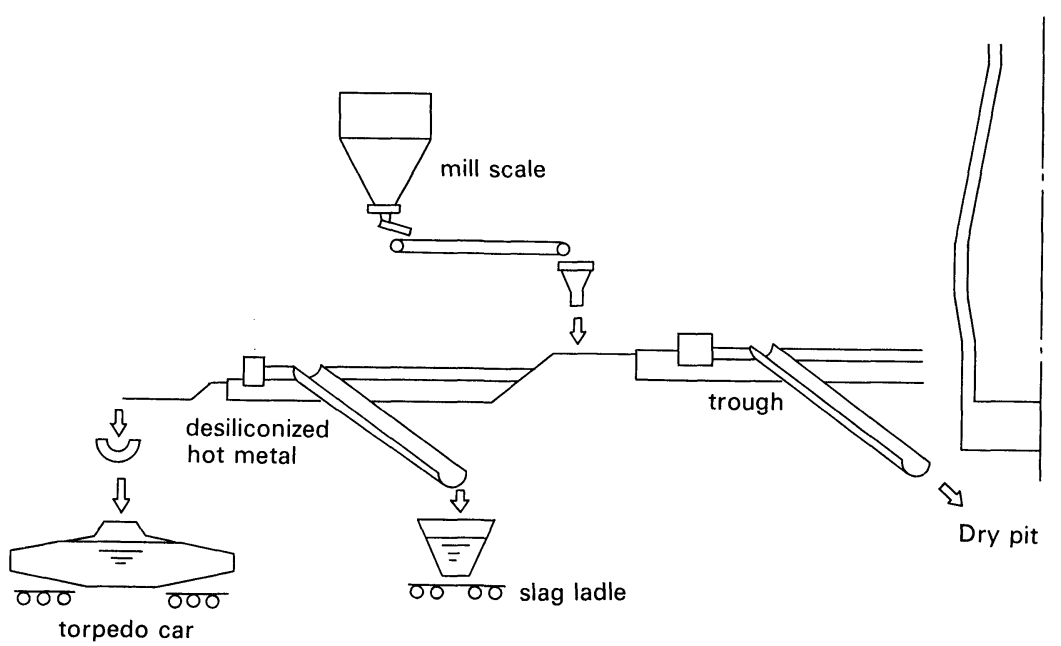

Fig. 11.

Mill scale addition at the blast furnace iron trough at Kakogawa Works, Kobe Steel, Ltd. 


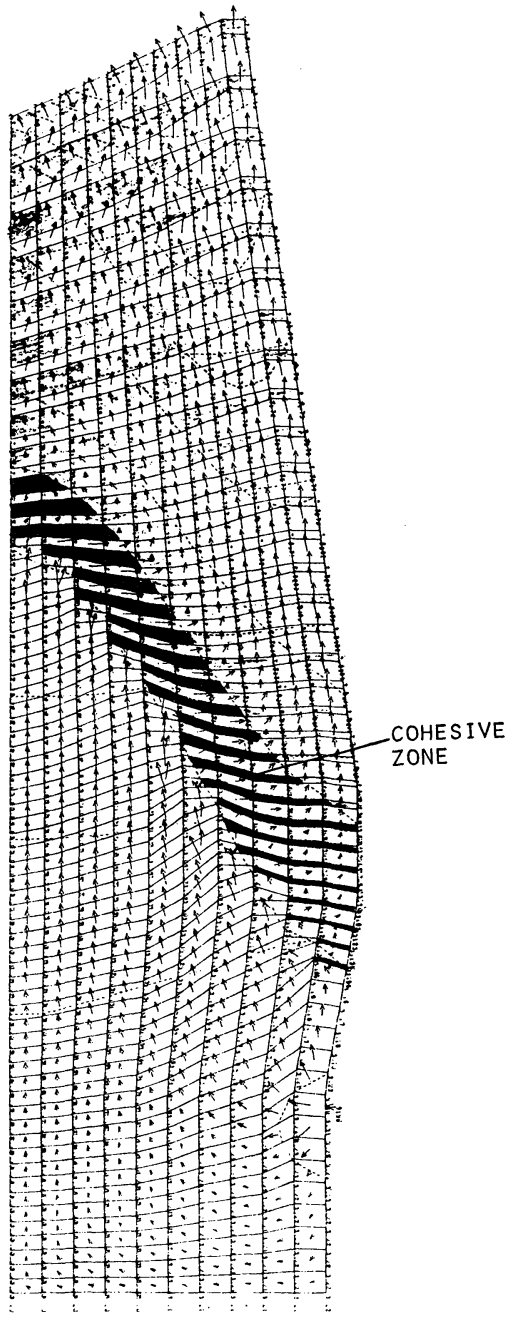

Fig. 12. An example of blast furnace inside as calculated by computer from the various kinds of data. (Ohgishima No. 1 BF of Nippon Kokan K.K.)

\section{Life of Blast Furnaces}

Several years ago, the life of a large blast furnace had generally been estimated to be 5 to 6 years on average. However, due to improvements in the gas flow control made possible by developing burden distribution control technology and by advances in the furnace body cooling and refractory technologies, the life of a blast furnace has gradually been extended. Some blast furnaces have been in operation for more than 10 years. (See Fig. 13.)

No. 3 BF in Kimitsu Works of Nippon Steel (inner volume $4052 \mathrm{~m}^{3}$ ) was in operation for 11 years and

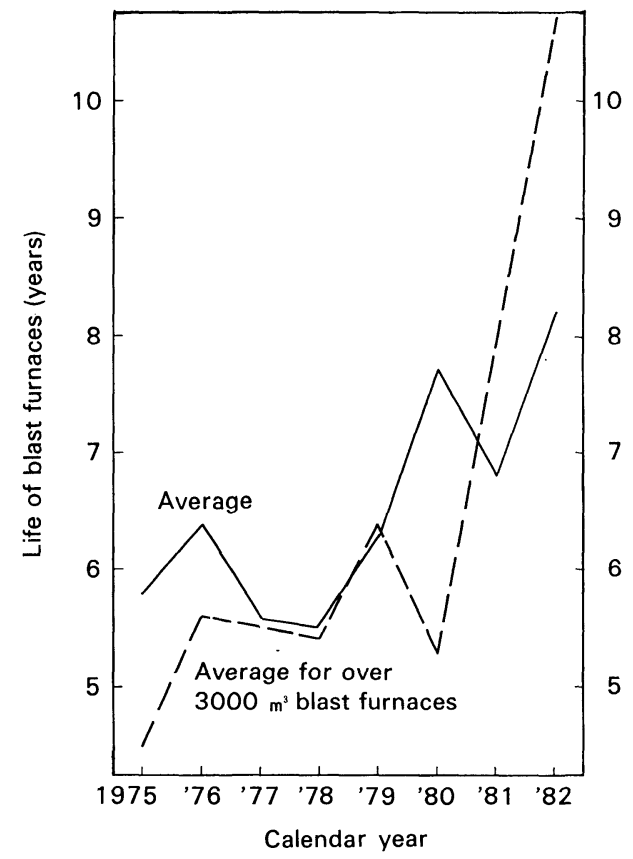

Fig. 13. Progress of average life of blown-out blast furnaces in Japan.

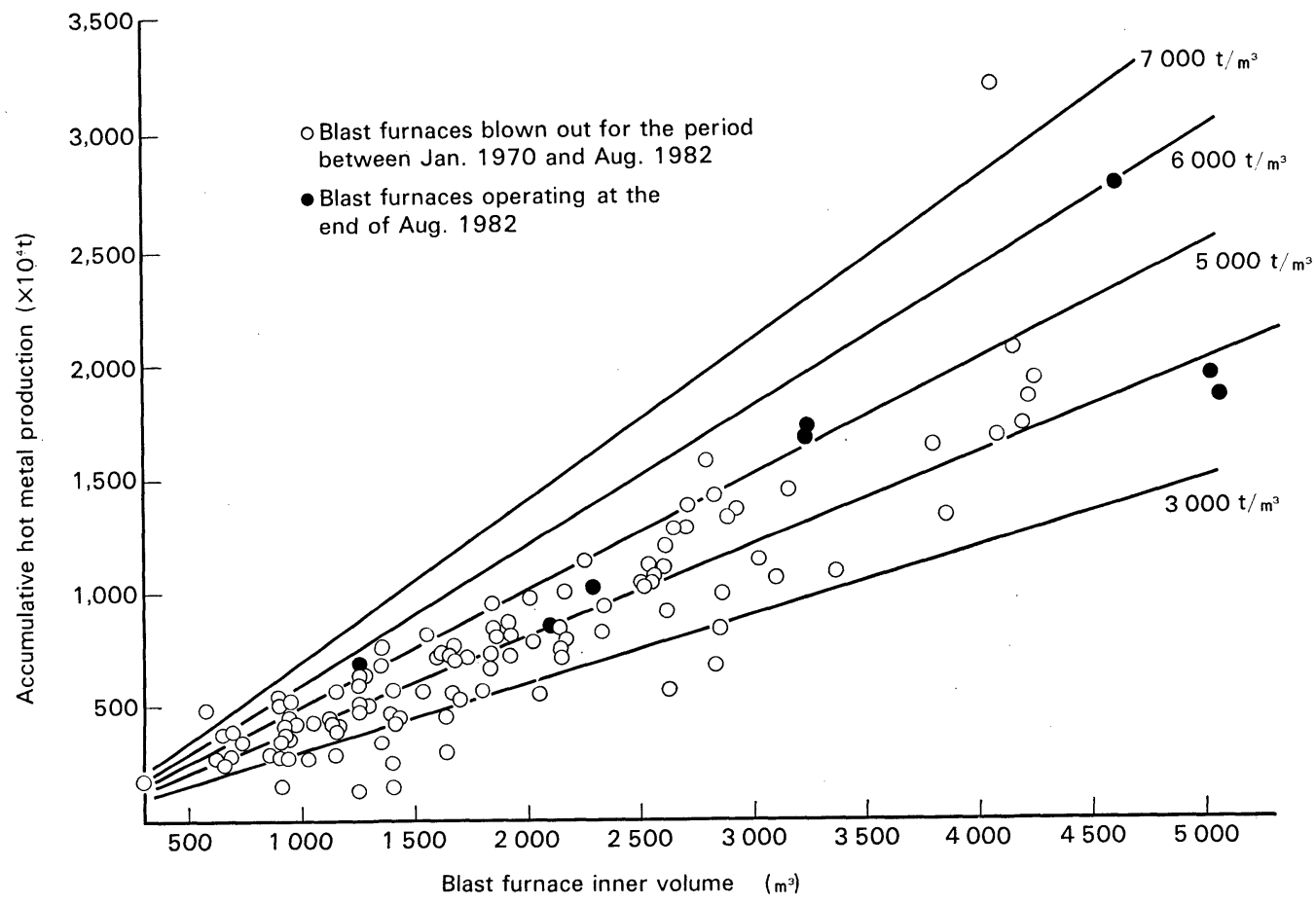

Fig. 15. Relation between accumulative hot metal production and blast furnace inner volume. 


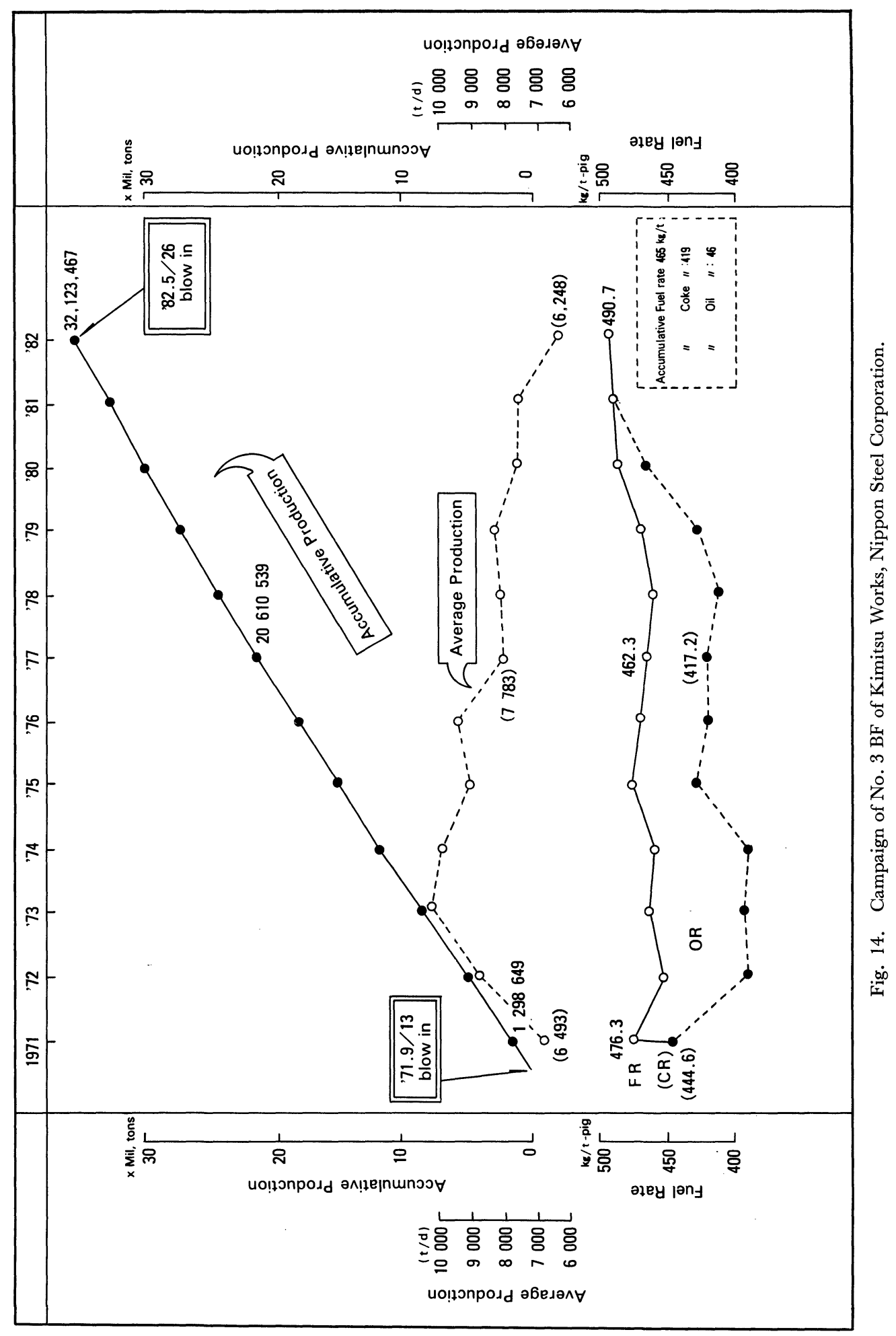

one month when it was blown out in May, 1982, producing 32.12 million $\mathrm{t}$ of pig iron on a cumulative basis. (See Fig. 14.) No. 5 BF at Fukuyama Works of Nippon Kokan (inner volume $4617 \mathrm{~m}^{3}$ ) has been operating for 9 years and 6 months by the end of April, 1983, producing a total of 30.76 million $\mathrm{t}$ of pig iron. As shown in Fig. 15 (in p. 251), blast furnaces have been operated with a cumulative hot metal production of 6000 to $7000 \mathrm{t} / \mathrm{m}^{3}$ of furnace inner volume.

The older the furnaces life become, the more often are they damaged and subjected to repair.

Although the development of operation and main- tenance technology has enabled most parts of the furnace body to be repaired during its campaign, erosion of brickworks at the middle and lower part of shaft and penetration of hot metal at hearth side wall are still left difficult to repair. The incidence of damaged or worn bricks in the shaft has certainly been reduced by using $\mathrm{SiC}$ and $\mathrm{SiC}-\mathrm{Si}_{3} \mathrm{~N}_{4}$ refractories (see Fig. 16), improved cooling systems including tuyeres, cooling staves systems, and cooling boxes, etc., using gunning and other repair techniques, and by establishing burden distribution control technique, a life of approximately 10 years can be assured. Figure 17 shows an 


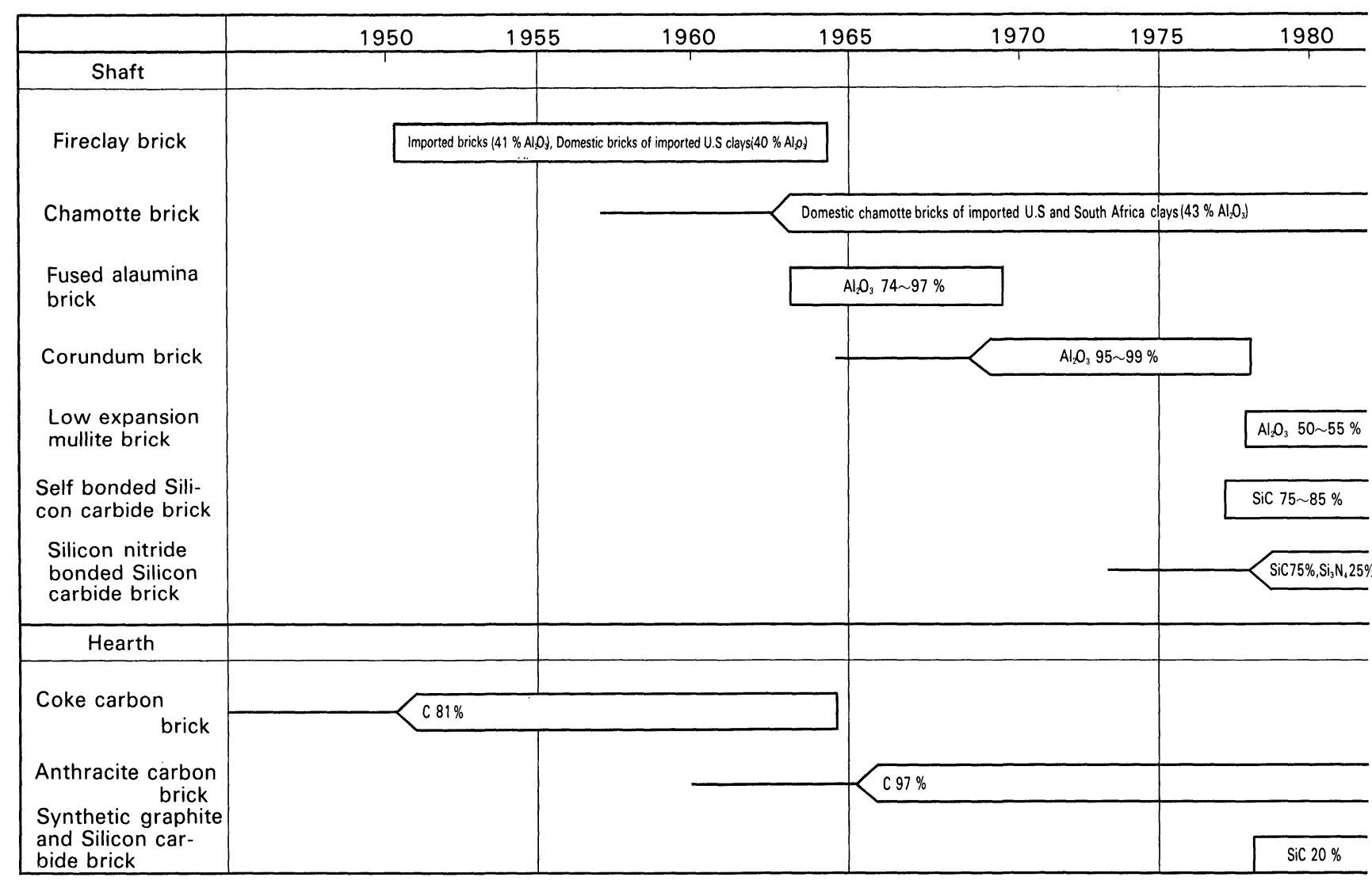

Fig. 16. Change in blast furnace refractories.

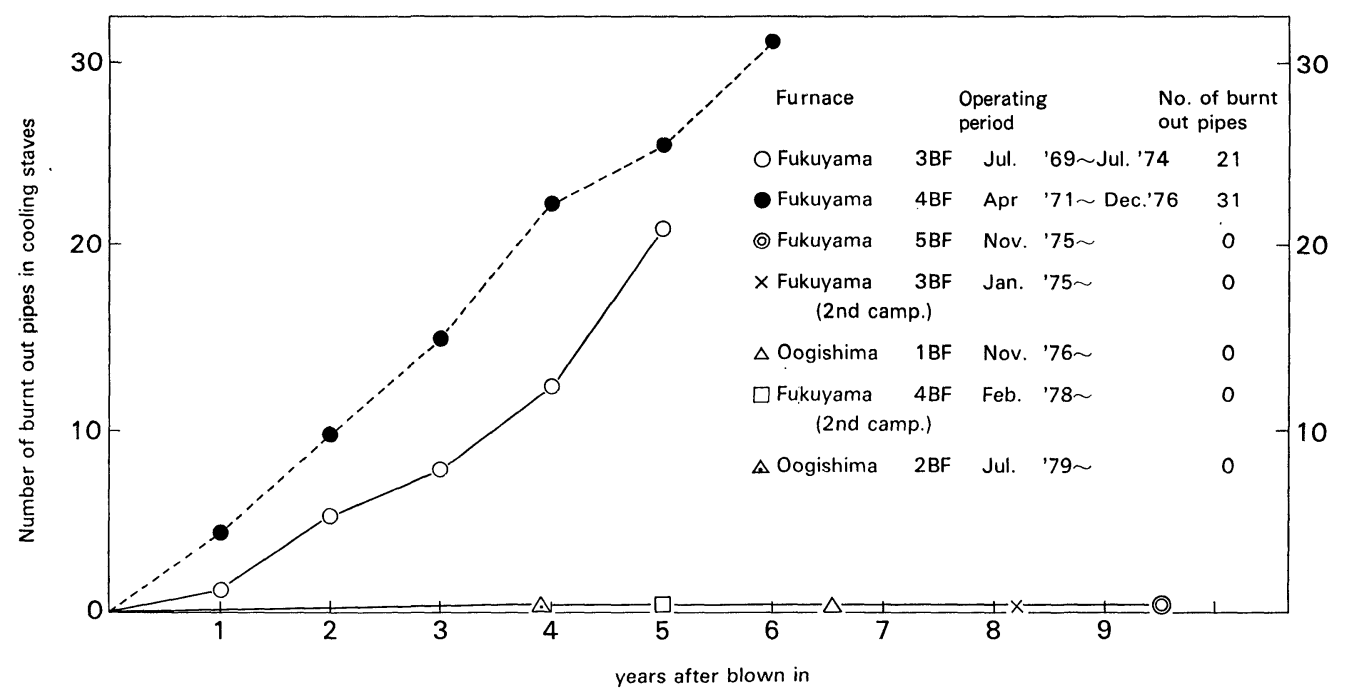

Fig. 17. Progress of number of burnt out cooling staves at Nippon Kokan K.K.

improved cooling stave used in the blast furnaces of Nippon Kokan. None of the cooling pipes embedded in Nippon Kokan cooling staves has ever been subject to burnt-out since the improvements were made in 1973.

Regarding furnace bottoms, whales are sometimes caused on hearth side walls of furnace bottoms with conventional carbon block constructions. Recently, carbon blocks made of a $\mathrm{C}-\mathrm{SiC}$ material have been used and are expected to greatly improve the situation due to their excellent resistance to erosion by hot metal and by alkali. Figure 18 shows the estimated furnace profile of Fukuyama No. 5 BF of Nippon
Kokan during operation. This blast furnace is expected the life of 10 years and is to be switched to Fukuyama No. $2 \mathrm{BF}$ which is being relined. It is not simply an engineer's dream to forecast a service life of 10 to 15 years and a cumulative hot metal production of 40 million $\mathrm{t}$ in a campaign by making further improvements.

\section{Conclusions}

Recent topics of interest on the blast furnace technology in Japan have been outlined. Details of the advances made in the probe and computer control technology, which characterizes Japan's blast furnace 


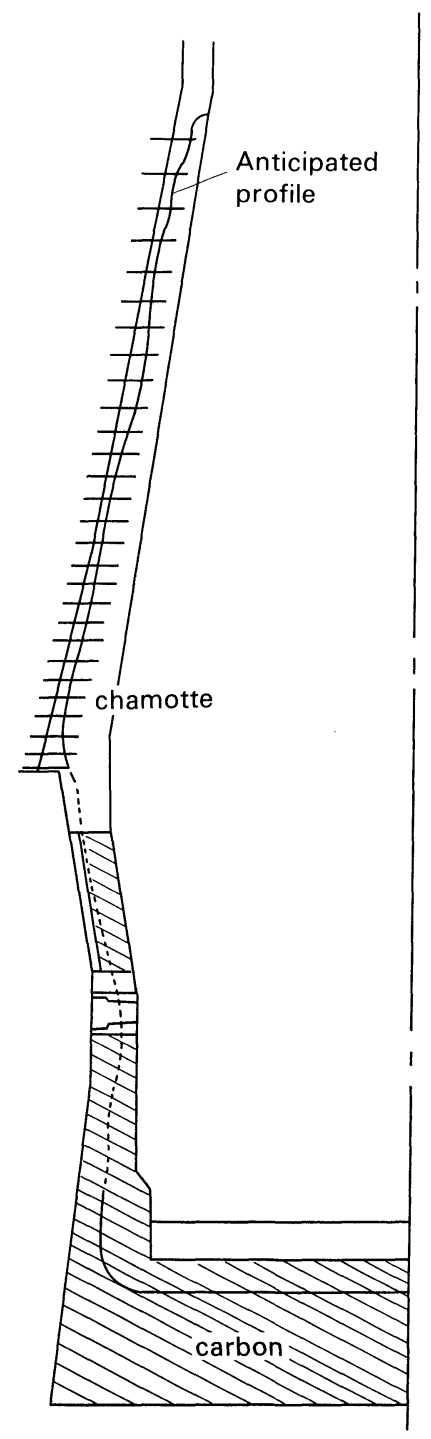

Fig. 18. Anticipated profile of No. 5 BF of Fukuyama Works, Nippon Kokan K.K. at the period of 9 years and 6 months after its blown-in.

technology, have mostly been omitted. The advances made in sensor technology have permitted collection of a large volume of accurate information. Progress made in analysis and computer technology has allowed various characteristic values to be translated into graphs or indexes for overall judgment. These represent major advances.

Blast furnace operating technology has undergone substantial change to cope with the effects of the oil crises between 1974 and 1978, and the change has been met by developing and implementing total and
Table 4. Low fuel operation at NKK Fukuyama 3BF.

\begin{tabular}{l|cc} 
& Jan. 1979 & Nov. 1981 \\
\hline Hot metal production $(\mathrm{t} / \mathrm{d})$ & 7436 & 7636 \\
Goke rate $(\mathrm{kg} / \mathrm{t})$ & 365 & 354 \\
Tar (heavy oil) rate $(\mathrm{kg} / \mathrm{t})$ & 63 & 42 \\
Fuel rate $(\mathrm{kg} / \mathrm{t})$ & 428 & 396 \\
Blast temperature $\left({ }^{\circ} \mathrm{C}\right)$ & 1316 & 1353 \\
Blast moisture $\left(\mathrm{g} / \mathrm{Nm}^{3}\right)$ & 6.3 & 5.6 \\
Percentage of sinter in burden (\%) & 80.8 & 96.6 \\
Percentage of $\mathrm{Si}$ in hot metal (\%) & 0.35 & 0.27 \\
\hline
\end{tabular}

cost-minimizing operation technology.

Nevertheless, the future economic and technological changes are totally unpredictable. New technologies for the next generation have to be developed when the situation has stabilized. Low fuel consumption operations conducted with Fukuyama No. 3 BF of Nippon Kokan is introduced in the following regarding this matter. As mentioned earlier, at present, high fuel ratio operations aimed at minimizing production cost are normally carried on. There are ample possibilities for low fuel ratio operations with changes in the fuel pricing structure. From such a viewpoint, two or three steel mills have been conducting tests of extremely low fuel ratio operations during the past several years. The Fukuyama No. $3 \mathrm{BF}$ of NKK has accomplished a low fuel ratio of $396 \mathrm{~kg} / \mathrm{t}$ (see Table 4) producing valuable lessons. This has been achieved through:

1) Good RI and RDI sinter

2) Control of burden and gas distributions by controlling the use of movable armour

3) Computer control system.

Serious studies will be continued in a wide range of technologies searching for tomorrow's technology, such as low silicon operation, desiliconization and dephosphorization outside furnaces, and lower relining costs.

As scrap is now beginning to be recycled in Japan, increases or decreases in crude steel and in pig iron are forecasted to take a different form to that previously experienced. The fluctuations for hot metal will be greater to that for crude steel, requiring more flexible blast furnace operations in which the generation of scrap is monitored.

Finally, all the figures and tables are presented by the courtesy of Nippon Steel, Nippon Kokan, Kawasaki Steel, Sumitomo Metal and Kobe Steel which are shown respectively in the paper. 